\title{
Genetic Transformation of Rifampicin Resistance in Lactobacillus acidophilus
}

\author{
By JANE H. -C. LIN AND DWAYNE C. SAVAGE* \\ Department of Microbiology, University of Illinois, Urbana, IL 61801, USA
}

(Received 21 November 1985; revised 7 March 1986)

\begin{abstract}
Lactobacillus acidophilus strain 100-33, originally isolated from swine faeces, was transformed to rifampicin resistance with DNA from spontaneous rifampicin-resistant mutants derived from it. Cells of the recipient strain were treated with lysozyme and mutanolysin, mixed with donor DNA and polyethylene glycol and grown on a regeneration medium overnight. After $48 \mathrm{~h}$ incubation, the numbers of rifampicin-resistant cells in the populations of regenerated cells were estimated from numbers of colonies. Efficiency of the lysozyme/mutanolysin treatment (the ratio of the number of osmotically fragile cells after the enzyme treatment to the initial cell number) was about $99 \%$. The regeneration frequency of the enzyme-treated cells varied from 5 to $67 \%$. The transformation frequency varied from about $0.2 \times 10^{-8}$ to $8.0 \times 10^{-8}$ transformants per regenerated cell per $\mu$ g DNA. To our knowledge, this method for genetic transformation is the first to be reported for a Lactobacillus strain.
\end{abstract}

\section{INTRODUCTION}

Species of the genus Lactobacillus are used extensively in the fermentation industry (Rose, 1981). These micro-organisms are also important inhabitants of the gastrointestinal tract of animals of various species (Savage, 1983). Research on the molecular biology of Lactobacillus has progressed slowly, however, partly because of the lack of systems for genetic transfer in this genus. We are studying properties of certain strains of indigenous lactobacilli (e.g. $L$. acidophilus) involved in their colonization of the murine gastric epithelium. The research includes attempts to develop systems for studying the genetics of such properties (Lin \& Savage, 1984 , 1985). We undertook, therefore, to develop a system for transferring genes by transformation from one $L$. acidophilus strain to another.

Lactobacilli have proved to be refractory to genetic transformation by methods in which intact recipient cells are exposed directly to donor DNA (Lee-Wickner \& Chassy, 1984). We confirmed this observation with our strains, and attempted, therefore, to develop a system in which the recipient cells were converted to protoplasts by treatment with muralytic enzymes, exposed to donor DNA and regenerated into intact cells. Efficient methods for producing and regenerating protoplasts have been reported for strains of $L$. casei (Lee-Wickner \& Chassy, 1984). The frequency of protoplast production in that species is reported to be nearly $100 \%$. The protoplasts can be regenerated with 10-40\% efficiency. In our hands, however, L. acidophilus strains treated with lysozyme and mutanolysin as described by Lee-Wickner \& Chassy (1984) yielded protoplasts with an efficiency of less than $1 \%$. Therefore, we tested the sensitivity of cells treated with the enzymes to lysis with sodium dodecyl sulphate (SDS) solution as an index of their competency to take up donor DNA. In this report, we document success in using such a method to transform cells of a strain of $L$. acidophilus derived from the faeces of a swine to resistance to an antibacterial drug (rifampicin). 


\section{METHODS}

Bacterial strains and cultural conditions. Lactobacillus acidophilus strain 100-33, originally isolated from pig faeces, was the recipient of transforming DNAs. This organism adheres to murine gastric epithelium, but does not colonize the keratinized squamous epithelium in the stomachs of monoassociated ex-germfree mice (Kotarski \& Savage, 1979). As the source of transforming DNA, spontaneous rifampicin-resistant ( Rif $^{\mathrm{r}}$ ) mutants were obtained of strain 100-33. About $10^{8}$ cells were spread on MRS medium (Difco) containing $2 \%(w / v)$ agar and $100 \mu \mathrm{g}$ rifampicin $\mathrm{ml}^{-1}$ (RIF-MRSA). After $2 \mathrm{~d}$ incubation, colonies were picked and restreaked on RIF-MRSA. Isolates from colonies grown on the second RIF-MRSA plates were designated strain 100-33 Rif $^{r}$. As determined by the tube dilution method (Anderson, 1970), the MIC of rifampicin for the parental strain was $0.6 \mu \mathrm{g} \mathrm{ml}^{-1}$, whereas for the Rif ${ }^{r}$ mutants, it was greater than $3 \mathrm{mg} \mathrm{ml}^{-1}$ (maximum solubility). The frequency of the spontaneous mutation was between $10^{-7}$ and $10^{-8}$. On RIF-MRSA, strain 100-33 Rif $^{r}$ normally gave rise to colonies with rough surfaces and undulate edges. Occasionally, colonies with smooth surfaces and entire edges were observed. We chose one of each colonial type, designated as 100-33 $\mathrm{R}^{\mathrm{f}}{ }^{\mathrm{r}} \mathrm{R}$ and 100-33 $\mathrm{Rif}$ ' $\mathrm{S}$, respectively, as donors of DNA for the transformation. Strains 100-33 Rif'R and 100-33 Rif'S were grown in MRS broth containing $100 \mu \mathrm{g}$ rifampicin $\mathrm{ml}^{-1}$ (RIF-MRSB). Strain 100-33 was grown in MRSB. Stocks of bacterial cultures were maintained at $-80^{\circ} \mathrm{C}$. Donors and recipient cells of transforming DNA were prepared as follows. A $7 \mathrm{ml}$ volume of appropriate growth medium was inoculated with $50 \mu \mathrm{l}$ of the frozen stock and incubated overnight at $37^{\circ} \mathrm{C}$. The overnight culture was subcultured (a $1: 100$ inoculum) and allowed to grow for $4 \mathrm{~h}$ at $37^{\circ} \mathrm{C}$. Tubes containing inoculated liquid media were incubated statically in air. All agar plates were incubated anaerobically in an atmosphere containing $92 \% \mathrm{~N}_{2}, 5 \% \mathrm{CO}_{2}$ and $3 \% \mathrm{H}_{2}$

Reagents, buffers and regeneration medium. Enzymes and chemicals were purchased from Sigma, with the following exceptions: SDS, from Pierce Chemical; gelatin from Baker \& Adamson; $\mathrm{MgCl}_{2}$ from J. T. Baker Chemical Co.; and $\mathrm{CaCl}_{2}$ from E. $\mathrm{K}$. Industries. TE is $10 \mathrm{~mm}-\mathrm{Tris} / \mathrm{HCl}$ and $1 \mathrm{~mm}-\mathrm{Na}{ }_{2} \mathrm{EDTA}$, pH 8.0. Protoplast formation buffer (PB) and regeneration medium (RM) were used as described by Lee-Wickner \& Chassy (1984) with modifications. Sorbitol $(0.5 \mathrm{M})$ was used as the osmotic stabilizer in PB; RM was MRSA containing $0.5 \mathrm{M}-$ sorbitol, $0.5 \%$ bovine serum albumin, $2 \cdot 5 \%(\mathrm{w} / \mathrm{v})$ gelatin, $25 \mathrm{mM}-\mathrm{MgCl}_{2}$ and $25 \mathrm{mM}-\mathrm{CaCl}_{2}$. Lysozyme used in treating the recipient cells for transformation was prepared in PB at a concentration of $10 \mathrm{mg} \mathrm{ml}^{-1}$. Mutanolysin at 5 units $\mu \mathrm{l}^{-1}$ was prepared in $0.1 \mathrm{M}$-potassium phosphate buffer, pH 6.2. Both enzymes were sterilized by filtration through $0.22 \mu \mathrm{m}$ membrane filters (Millipore). DNAase was prepared in PB at a concentration of $4 \mu \mathrm{gl}^{-1}$ and used without sterilization; the preparation contained no viable cells detectable by culture on MRSA and RIF-MRSA.

DNA for transformation. A method described for plasmid isolation (Lin \& Savage, 1985) was used with modifications. Cultures $(40 \mathrm{ml})$ of strains $100-33 \mathrm{Rif}^{\mathrm{r}} \mathrm{R}$ and 100-33 $\mathrm{R}$ if ${ }^{\mathrm{r}} \mathrm{S}$ were grown to mid-exponential phase (3$5 \times 10^{8}$ c.f.u. $\left.\mathrm{ml}^{-1}\right)$. The cells were harvested by centrifugation $\left(12000 \mathrm{~g}\right.$ at $4{ }^{\circ} \mathrm{C}$ for $\left.15 \mathrm{~min}\right)$, washed once and then resuspended in $2.5 \mathrm{ml} 0.01 \mathrm{M}$-Tris $/ \mathrm{HCl}, \mathrm{pH} 8 \cdot 2$. Lysozyme ( $1 \mathrm{ml}$ of $6 \mathrm{mg} \mathrm{ml}^{-1}$ solution in the same buffer $)$ was then added. After $1 \mathrm{~h}$ incubation at $37^{\circ} \mathrm{C}$, the cells were lysed with $1 \%(\mathrm{w} / \mathrm{v})$ SDS. Lysate preparations were diluted with $4 \mathrm{ml} 0.01 \mathrm{M}$-Tris/ $\mathrm{HCl}$, digested with $100 \mu \mathrm{g}$ RNAase $\mathrm{ml}^{-1}$ at $37^{\circ} \mathrm{C}$ for $1 \mathrm{~h}$, extracted twice with phenol, once with chloroform/isoamyl alcohol $(24: 1, \mathrm{v} / \mathrm{v})$ and then precipitated with absolute ethanol (final concentration of ethanol $70 \%, \mathrm{v} / \mathrm{v}$ ). The precipitates were rinsed with $70 \%$ ethanol, dried under vacuum and stored at $4{ }^{\circ} \mathrm{C}$. Dried precipitates were dissolved in $400 \mu \mathrm{l} \mathrm{TE}$ just before use in transformation experiments. DNA concentrations were determined spectrophotometrically (Maniatis et al., 1982).

Recipients for transformation. Cultures $(7 \mathrm{ml})$ of strain $100-33$ were grown to mid-exponential phase $(1-5 \times$ $10^{8}$ c.f.u. $\left.\mathrm{ml}^{-1}\right)$. The cells were harvested by centrifugation $(1750 \mathrm{~g}$ at room temperature for $20 \mathrm{~min})$, resuspended in $1 \mathrm{ml} \mathrm{PB}$, transferred to Eppendorf tubes and then pelleted in a microfuge (Brinkmann Instruments) for $10 \mathrm{~min}$. Washed cells were resuspended in $625 \mu \mathrm{l} \mathrm{PB}$, to which $70 \mu \mathrm{l}$ lysozyme and $5 \mu \mathrm{l}$ mutanolysin were added. The enzyme/cell mixtures were incubated at $37^{\circ} \mathrm{C}$ until the cells could be lysed with $1 \%$ (w/v) SDS (usually $10-20 \mathrm{~min}$ ). Treated cells were sedimented by centrifugation $(5 \mathrm{~min})$ and resuspended in $700 \mu \mathrm{l}$ PB by brief agitation with a vortex mixer. At this point, they were used either in transformation experiments (see below) or for estimating the efficiency of the enzyme treatment and regeneration frequency. In the latter case, 10-fold dilutions of the cells made in water and PB were plated on MRSA and RM, respectively. Population estimates were made from numbers of colonies on plates incubated overnight. The efficiency of the enzyme treatment was defined as the ratio of the number of osmotically fragile cells after enzyme treatment to the initial cell number. The regeneration frequency was defined as net regenerants per osmotically fragile cell.

Transformation. Transforming DNAs were mixed with $2 \times \mathrm{PB}$ at equal volume (usually $90 \mu \mathrm{l}$ ) in an Eppendorf tube. Freshly prepared recipient cells $(70 \mu \mathrm{l})$ were added to the DNA mixtures followed by 3 vols $40 \%(\mathrm{w} / \mathrm{v})$ polyethylene glycol (PEG) 6000 in PB. The materials were mixed by agitation with a vortex mixer and incubated at room temperature for $20 \mathrm{~min}$. The cells were then pelleted by centrifugation at room temperature for $5 \mathrm{~min}$. After removal of the supernatant solutions, the pellets were resuspended in $200 \mu \mathrm{l} \mathrm{PB}$ and divided into two portions, each of which was spread on an RM plate. After overnight incubation, cells were washed from the plates, first with 
$1 \mathrm{ml} \mathrm{PB}$ and then with $1 \mathrm{ml}$ water. Tenfold dilutions of the washes were then plated on MRSA or RIF-MRSA. The populations were estimated from numbers of colonies on the plates after $48 \mathrm{~h}$ incubation. The following controls were included in each experiment : (a) $90 \mu \mathrm{l} \mathrm{TE}$ to replace transforming DNAs, $(b) 7 \mathrm{ml}$ uninoculated MRSB to replace cultures of strain 100-33, (c) transforming DNAs treated with $400 \mu \mathrm{g}$ pancreatic DNAase ml-1 for $1 \mathrm{~h}$ at room temperature before mixing with $2 \times$ PB. The transformation frequency was defined as number of Rif $r$ transformants per regenerated cell less the number of spontaneous Rif ${ }^{r}$ mutants per regenerated cell per $\mu \mathrm{g}$ DNA.

\section{RESULTS}

Efficiency of enzyme treatment and regeneration frequency. When cells of strain 100-33 at midexponential growth phase were subjected to lysozyme and mutanolysin digestion at final concentrations of $1 \mathrm{mg} \mathrm{ml}^{-1}$ and 36 units $\mathrm{ml}^{-1}$, respectively, about $99 \%$ of the population was made osmotically fragile. Among these fragile cells, 5-67\% regenerated on RM after overnight incubation. The incubation time required for regeneration is much shorter than that reported by Lee-Wickner \& Chassy (1984) (overnight vs 5-7 d). We have also tested this method on $L$. fermentum strain 100-16 (Kotarski \& Savage, 1979; Lin \& Savage, 1984, 1985), and achieved a $99.95 \%$ efficiency of the enzyme treatment and a $13 \%$ regeneration frequency. Such findings suggest that the method may be applicable to other species of lactobacilli.

Method for estimating transformation frequency. An indirect method was used to evaluate transformation of strain 100-33 to rifampicin resistance. As reported for Bacillus subtilis (Chang \& Cohen, 1979), cells of $L$. acidophilus strain 100-33 treated with lysozyme and mutanolysin do not regenerate in broth. In addition, cells of strains 100-33 regenerated on plates cannot be transferred efficiently to RIF-MRSA by replica plating with velvet (unpublished observation). Moreover, accurate estimates could not be made of numbers of cells of strain 100-33 harvested from transformation mixtures, grown on RM for several hours, and overlaid with a medium containing rifampicin. PEG present in the transformation mixture caused the bacterial cells to aggregate. Therefore, in attempts to develop a direct-selection method, we found that we could not estimate with sufficient accuracy the levels of the bacterial populations. Spontaneous Rif ${ }^{r}$ mutants were always present in the recipient population, requiring us to compare the ratio of the number of Rif ${ }^{r}$ cells to the total number in the experimental group with that ratio in a control group where transforming DNA was replaced by TE buffer. Therefore, as a reliable method to quantify cell numbers, we developed and used an indirect-selection method (see Methods).

Transformation. PEG facilitated transformation of strain 100-33 to rifampicin resistance. Without PEG in the mixtures, the transformation frequency ranged from $0.1 \times 10^{-8}$ to $0.2 \times$ $10^{-8}$ transformants per regenerated cell per $\mu$ g DNA. With PEG present in the transformation mixtures, the frequencies ranged from $1.5 \times 10^{-8}$ to $3.2 \times 10^{-8}$, (mean $2.2 \times 10^{-8}$ ) (Table 1 ). The frequency tended to be related to the amount of DNA used (Table 2).

Effect of DNAase on transformation. When the DNA was hydrolysed with DNAase and PEG was present (Table 1), the transformation frequencies were about the same as were detected with intact DNA but with no PEG in the transformation mixture.

Effect of the source of DNA on transformation. Two colonial types of strain 100-33 Rif ${ }^{\mathrm{r}}$ were used as DNA donors: a predominant rough type ( $\left.\operatorname{Rif}^{r} R\right)$ and a less-frequent smooth type $\left(\right.$ Rif $\left.^{r} \mathrm{~S}\right)$. Four preparations of DNA were obtained from cells of strain Rif $\mathrm{S}$, and used in attempts to transform the parental strain to rifampicin resistance. In the four trials, the transformation frequencies ranged from $0.5 \times 10^{-8}$ to $2.0 \times 10^{-8}$ (mean $0.9 \times 10^{-8}$ ), substantially below the values obtained with DNA from strain 100-33 Rif ${ }^{r} R$ (Table 1).

Stability of transformants. The Rif ${ }^{r}$ transformants were stable. Over 300 Rif $^{r}$ colonies from the transformation experiments with DNAs from cells of both 100-33 Rif ${ }^{r} R$ and 100-33 Rif ${ }^{r} S$ were randomly picked and transferred daily on MRSA for 6 consecutive days; on day 7, the isolates were grown on RIF-MRSA. After overnight incubation, all of the isolates grew as well on RIFMRSA as on MRSA after overnight incubation. 
Table 1. Transformation of L. acidophilus strain 100-33 to rifampicin resistance

DNA was from L. acidophilus strain 100-33 Rif'R; PEG was present in the mixtures. The results are the arithmetic means of results from four separate experiments, with the ranges shown in parentheses.

\begin{tabular}{|c|c|c|c|}
\hline \multirow{2}{*}{$\begin{array}{c}\text { DNA in } \\
\text { transformation } \\
\text { mixture }(\mu \mathrm{g})\end{array}$} & \multicolumn{2}{|c|}{ Regenerated population } & \multirow[b]{2}{*}{$\begin{array}{c}10^{8} \times \\
\text { transformation } \\
\text { frequency* }\end{array}$} \\
\hline & $\begin{array}{l}\text { Total } \\
\left(10^{-10} \times \text { c.f.u. } \mathrm{ml}^{-1}\right)\end{array}$ & $\left(10^{-3} \times\right.$ Rif ${ }^{r}$ c.f.u. $\left.\mathrm{ml}^{-1}\right)$ & \\
\hline None & $0.8(0.4-1.3)$ & $0.6(0 \cdot 1-1 \cdot 1)$ & - \\
\hline 157 & $1 \cdot 2(0 \cdot 5-2 \cdot 3)$ & $36.0(8.0-74.0)$ & $2 \cdot 2(1 \cdot 5-3 \cdot 2)$ \\
\hline 157 + DNAaset & $0.6(0.3-1.0)$ & $0.9(0.2-1.5)$ & $0.2(0-0.6)$ \\
\hline
\end{tabular}

\footnotetext{
* Expressed as [(no. of Rif ${ }^{r}$ transformants/total regenerated population) - (no. of Rif ${ }^{r}$ mutants/total regenerated population)]/amount of DNA $(\mu \mathrm{g})$ in transformation mixture.

$\dagger$ Digested with $400 \mu \mathrm{g}$ DNAase $\mathrm{ml}^{-1}$ at room temperature for $1 \mathrm{~h}$.
}

Table 2. Effect of DNA quantity on transformation of L. acidophilus strain 100-33 to rifampicin resistance

\begin{abstract}
Conditions were as described for Table 1. Each quantity of DNA used represents a separate experiment; each was separately controlled. The results are from individual experiments except where no DNA was present, where means and ranges of four experiments are shown.
\end{abstract}

\begin{tabular}{|c|c|c|c|}
\hline \multirow{2}{*}{$\begin{array}{l}\text { DNA in } \\
\text { transformation } \\
\text { mixture }(\mu \mathrm{g})\end{array}$} & \multicolumn{2}{|c|}{ Regenerated population } & \multirow{2}{*}{$\begin{array}{c}10^{8} \times \\
\text { transformation } \\
\text { frequency* }\end{array}$} \\
\hline & $\begin{array}{l}\text { Total } \\
\left(10^{-10} \times \text { c.f.u. } \mathrm{ml}^{-1}\right)\end{array}$ & 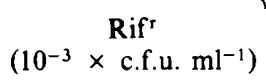 & \\
\hline None & $3.0(1 \cdot 3-3 \cdot 8)$ & $2 \cdot 0(1 \cdot 1-2 \cdot 9)$ & - \\
\hline 157 & $2 \cdot 3$ & 74.0 & $2 \cdot 0$ \\
\hline 187 & $3 \cdot 3$ & $127 \cdot 0$ & $2 \cdot 0$ \\
\hline 248 & $3 \cdot 5$ & $233 \cdot 0$ & $2 \cdot 6$ \\
\hline 286 & 3.8 & 886.0 & $8 \cdot 1$ \\
\hline
\end{tabular}

\title{
DISCUSSION
}

Cells of $L$. acidophilus strain 100-33 made sensitive to lysis with SDS were used as recipients of donor DNAs in various transformation experiments. In these experiments we made several observations. (a) As reported for bacteria of other genera (Chang \& Cohen, 1979; Fornari \& Kaplan, 1982; Santamaria et al., 1985), PEG facilitates transformation of L. acidophilus strain 100-33. (b) Strain 100-33 can be transformed to rifampicin resistance with DNAs from both colonial types of its spontaneous Rif $^{r}$ mutants. However, DNA from strain 100-33 Rif ${ }^{r} R$ yields higher transformation frequencies than DNA from strain 100-33 Rif ${ }^{r} S$. Strain 100-33 Rif ${ }^{r} S$ has a longer generation time in RIF-MRSB than 100-33 R if $' R$ (unpublished observation). Thus, the transformation frequency may have differed because the genetic property of rifampicin resistance (Godfrey \& Bryan, 1984) differs in the two colonial types. (c) The genetic characteristic transformed was stably maintained. After six passages on a non-selective medium, the transformants were still able to grow overnight on the medium containing rifampicin. (d) Transformation is dependent on the concentration of the donor DNA (Fornari \& Kaplan, 1982). We are using these findings to study the genetics of properties of lactobacilli involved in their colonization of the surface of the squamous epithelium in the murine stomach (Lin \& Savage, 1984).

The research was supported by Public Health Service grant AI-1 1858 from the National Institute of Allergy and Infectious Diseases. We express appreciation to D. D. Whitt and D. M. McCarthy for their excellent technical assistance, and to L. Nappe for preparing the manuscript by word-processing. 


\section{REFERENCES}

ANDERSON, T. F. (1970). Testing of susceptibility to antimicrobial agents and assay of antimicrobial agents in body fluids. In Manual of Clinical Microbiology, pp. 299-310. Edited by J. E. Blair, E. H. Lennette \& J. P. Truant. Baltimore: Williams \& Wilkins.

Chang, S. \& Cohen, S. N. (1979). High frequency transformation of Bacillus subtilis protoplasts by plasmid DNA. Molecular and General Genetics 168 , 111-115.

ForNARI, C. S. \& KaPlan, S. (1982). Genetic transformation of Rhodopseudomonas sphaeroides by plasmid DNA. Journal of Bacteriology 152, 89-97.

Godfrey, A. J. \& BryaN, L. E. (1984). Intrinsic resistance and whole cell factors contributing to antibiotic resistance. In Antimicrobial Drug Resistance, pp. 135-136. Edited by L. E. Bryan. Orlando: Academic Press.

Kotarski, S. F. \& Savage, D. C. (1979). Models for study of the specificity by which indigenous lactobacilli adhere to murine gastric epithelia. Infection and Immunity 26, 966-975.

Lee-WiCKNeR, L.-J. \& Chassy, B. M. (1984). Produc- tion and regeneration of Lactobacillus casei protoplasts. Applied and Environmental Microbiology 48, 994-1000

LIN, J. H.-C. \& Savage, D. C. (1984). Host specificity of the colonization of murine gastric epithelium by lactobacilli. FEMS Microbiology Letters 24, 67-71.

LiN, J. H.-C. \& Savage, D. C. (1985). Cryptic plasmids in Lactobacillus strains isolated from the murine gastrointestinal tract. Applied and Environmental Microbiology 49, 1004-1006.

Maniatis, T., Fritsch, E. F. \& SambrooK, J. (1982). Molecular Cloning, A Laboratory Manual, p. 468. Cold Spring Harbor, NY: Cold Spring Harbor Laboratory.

Rose, A. H. (1981). The microbial production of food and drink. Scientific American 245, 127-138.

Santamaria, R. I., Gil, J. A. \& Martin, J. F. (1985). High frequency transformation of Brevibacterium lactofermentum protoplasts by plasmid DNA. Journal of Bacteriology 162, 463-467.

Savage, D. C. (1983). Morphological diversity among members of the gastrointestinal microflora. International Review of Cytology 82, 305-334. 